\title{
Experimental Exergetic Performance Evaluation of an Elevator Air Conditioner Using R-1234yf
}

\author{
M. Araz, A. Güngör, and A. Hepbasli
}

\begin{abstract}
In this study, an elevator air conditioning (EAC) prototype, designed and manufactured at a factory located in Izmir, Turkey, is considered to assess its performance using exergy analysis method. The analyses performed include two various refrigerants, namely $R-134 a$ and $R-1234 y f$. The maximum improvement potential is found to be in the condenser for R-134a, while it is in the compressor for R-1234yf. The COP values are determined to be 2.550 and 2.33, while the product/fuel based exergy efficiencies are determined to be $58.72 \%$ and $57.39 \%$ for $R-134 a$ and $R-1234 y f$, respectively. The biggest irreversibility occurred in the compressor for both refrigerants. The exergy loss and flow diagram (the so-called Grassmann diagram) is also presented for the EAC studied to give quantitative information regarding the proportion of the exergy input that is dissipated in the various system components.
\end{abstract}

Index Terms-Elevator air conditioning, exergy analysis, R-1234yf, R-134a.

\section{INTRODUCTION}

Refrigeration history goes back to ancient times, where stored ice, vaporization of water and other evaporative processes are used. In the 1830 s, Perkins has invented the first vapor compression machine and introduced us with the refrigerants. At those times every fluid that works and was available was used. After that the specifications that we want from a refrigerant showed changes with time. Today, refrigerants should have zero ozone depletion potential (ODP), low global warming potential (GWP), short atmospheric lifetime and high efficiency, as a consequence of the legislations, namely the Kyoto Protocol, the F-Gas Regulation and MAC (mobile air conditioning) Directive, which have come into force [1]. Especially the MAC Directive [2] puts some certain restrictions to the use of refrigerants in mobile air conditioning systems. According to this directive, refrigerants with a GWP of higher than 150 shall not be used in all new vehicle models starting from 1 January 2011 and with effect from 1 January 2017 in all new vehicles. The immediate effect of this regulation is the ban of R-134a in MACs, where it's mostly used. Recently (on $12^{\text {th }}$ of March) European Parliament has formally adopted the new F-Gas Regulation [3], which has put strict restrictions to refrigeration applications related to the use of $\mathrm{HFC}$

Manuscript received April 25, 2014; revised June 26, 2014. This work was supported in part by the Republic of Turkey Ministry of Science, Industry and Technology under the "SAN-TEZ" program.

M. Araz and A. Hepbasli are with the Department of Energy Systems Engineering, Yasar University, 35100 Bornova, İzmir, Turkey (e-mail: \{mustafa.araz, arif.hepbasli\}@yasar.edu.tr)

A. Güngör is with the Department of Mechanical Engineering, Ege University, 35100 Bornova, İzmir, Turkey (e-mail: ali.gungor@ege.edu.tr). refrigerants. Bans on HFCs in new equipment according to this regulation are listed below.

- Domestic refrigerators and freezers that contain HFCs with GWP $\geq 150$ as of 1 January 2015 ,

- Refrigerators and freezers for commercial use (hermetically sealed equipment) that contain HFCs with GWP $\geq 2500$ as of 1 January 2020 and HFCs with GWP $\geq 150$ as of 1 January 2022,

- Movable room air-conditioning equipment (hermetically sealed equipment which is movable between rooms by the end user) that contain HFCs with GWP 150 as of 1 January 2020,

- Single split air-conditioning systems containing less than $3 \mathrm{~kg}$ of fluorinated greenhouse gases, that contain, or whose functioning relies upon, fluorinated greenhouse gases with GWP $\geq 750$ as of 1 January 2015 .

As a consequence of all these restrictions, utilization of various environmentally friendly alternative refrigerants with low GWP has become essential. These alternatives can be divided into three main groups as follows: (i) HFCs with a GWP of less than 150 (e.g. R-152a), (ii) Natural refrigerants (such as ammonia, carbon dioxide and hydrocarbons), and (iii) New refrigerants (HFOs like R-1234ze, R-1234yf). $\mathrm{R}-1234 \mathrm{yf}$, also called as HFO-1234yf, is a new refrigerant developed by joint work of Honeywell and DuPont to replace $\mathrm{R}-134 \mathrm{a}$ in MAC systems. It has similar thermophysical properties to R-134a, thus can be used without any equipment changes or with some minor changes. It has excellent environmental properties with a ODP value of 0 , GWP of 4 and atmospheric lifetime of 11 days [4].

Because R-1234yf is a new refrigerant, numerous studies on its thermodynamic properties, safety, stability and performance have been performed by various researchers, producers and automobile industry. In this regard, Tanaka and Higashi [5] measured the thermodynamic properties of R-1234yf. They calculated the vapor and liquid densities by the Peng-Robinson and Hankinson-Thomson equations while the heat of vaporization was also determined. They concluded that almost all thermodynamic properties of $\mathrm{R}-1234 \mathrm{yf}$ were lower than those of R-134a. Because safety is the key factor for the acceptance of a new refrigerant, numerous tests and risk assessments were conducted regarding its flammability, toxicity. The results of the risk assessment were presented in the report prepared by Lewandowski for SAE International Cooperative Research Program CRP1234-4 [6]. According to the report, "the estimated probability of vehicle occupant being exposed to a vehicle fire due to R-1234yf ignition (due to leak and ignition in engine compartment)" was $3 \times 10^{-12}$ (probability per vehicle per operating hour). Koban [7] presented the results 
related to material compatibility, stability and also miscibility in oils of R-1234yf. She reported that SAE CRP1234-2 and JAMA results indicated good compatibility and thermal stability with various commercially available common automotive materials while R-1234yf was more miscible with POE lubricants than R-134a. Ikegami et al., [8] used life cycle climate performance (LCCP) method to evaluate the environmental performance of R-1234yf in comparison with $\mathrm{R}-744$. Based on the results reported, the use of R-1234yf would lead to a $12 \%$ decrease in $\mathrm{CO}_{2}$ emissions in 2017 with the assumption of $43 \%$ alternative refrigerant usage. On the other hand, in a report prepared by Kauffeld [9], it is stated that there are concerns related to the effects of the use of HFOs (hydrofluoroolefins) on large scale, regarding the environment. In a study carried out by Jarahnejad [4], the performance of R-1234yf was compared to that of R-134a at 10 different heat load rates between $1 \mathrm{~kW}$ and $3.2 \mathrm{~kW}$. According to the test results, R-134a had in average $0-3 \%$ higher volumetric cooling capacity while R-1234yf had $0-8 \%$ lower volumetric compression work at condensing temperatures of $30{ }^{\circ} \mathrm{C}$ and $40{ }^{\circ} \mathrm{C}$. The COP value of R-134a was in average $2-15 \%$ higher than that of R-1234yf. R-134a also showed better performance in terms of heat transfer coefficient. In another experimental study performed by well-known automobile manufacturers, the performance of $\mathrm{R}-1234 \mathrm{yf}$ has been investigated on a vehicle. In the drop-in tests, R-1234yf had a COP value of 2.18 while the COP of R-134a was 2.24. After the optimization of the system (increasing subcooling by $30 \%$ and thermal expansion valve setting from 2 bars to 2.3 bars), R-1234yf reached the level of $\mathrm{R}-134 \mathrm{a}$ in terms of COP [10]. There are also studies on new developmental refrigerants (DR), which are mainly mixtures of R-1234yf and other refrigerants. The aim of DRs is to increase the performance of the system while keeping the GWP under a certain level at the same time. Leck [11] developed a theoretical refrigeration cycle model to show the performance and environmental characteristics of DRs and compared their capacities and COPs to that of R-410A. All the new blends presented a better COP value than that of R-410A while the capacities and GWP values were lower.

Exergy analysis is a very effective tool in evaluating system performance and optimizing energy savings. In this regard, various studies have been conducted related to heat pumps and refrigeration systems. Hepbasli [12] applied exergy modeling to a solar assisted domestic hot water tank integrated ground-source heat pump (GSHP) system. The exergy efficiencies on a product/fuel basis were found to be $72.33 \%$ for the GSHP, $14.53 \%$ for the solar domestic hot water system and $44.06 \%$ for the whole system. Ahamed et al., [13] reviewed exergy analysis of vapor compression refrigeration systems in their study. They investigated the effect of refrigerant on exergy analysis/parameters, and the effects of evaporating and condensing temperatures, reference state, lubricant and additives on exergy losses. They concluded that major exergy losses are occurred in the compressor among the components of the vapor compression system. Özgür et al., [14] theoretically investigated energetic and exergetic performance of R-134a in comparison with R-1234yf. They concluded that there were not any important differences between exergy efficiencies of both refrigerants.
$\mathrm{R}-1234 \mathrm{yf}$ was handled in more detail in previous studies [15], [16] and therefore no information related to its main properties will be given here. The main objective of this contribution is experimentally investigate the performance of an elevator air conditioner (EAC) prototype, designed and manufactured at a factory located in Izmir, Turkey. Two different refrigerants, R-134a and the new LGWP refrigerant R-1234yf, have been tested on the prototype without making any changes on the system. Energy and exergy analyses of the system are performed and the obtained results are compared to each other.

\section{EXPERIMENTAL SET-UP}

\section{A. Test Facility}

The experiments have been conducted at the performance test facility of the factory, as shown in Fig. 1. The test facility consists of two separate parts to simulate outdoor and indoor environments. The outdoor room dimensions are $5 \mathrm{~m} \times 14 \mathrm{~m}$ $\times 6.5 \mathrm{~m}$ while there is a $12 \mathrm{~m}$ test car inside, which can be divided into smaller volumes using separators. Inside the outer room, there are 10 refrigeration devices, each with a capacity of $2.35 \mathrm{~kW}$ and a $34.87 \mathrm{~kW}$ burner. Using these devices, it is possible to reach temperatures between $-20{ }^{\circ} \mathrm{C}$ and $+55^{\circ} \mathrm{C}$. In this study, an $11 \mathrm{~m}^{3}$ inner volume has been used. The outdoor room temperature was set to $35{ }^{\circ} \mathrm{C} \pm 2$. Because there were not any temperature and humidity control devices in the inner room, the tests have been conducted starting with an indoor temperature of $35^{\circ} \mathrm{C}$ decreasing with time. To maintain a relatively smaller decrease, an internal heat gain rate of $1 \mathrm{~kW}$ was maintained by using an electrical heater.

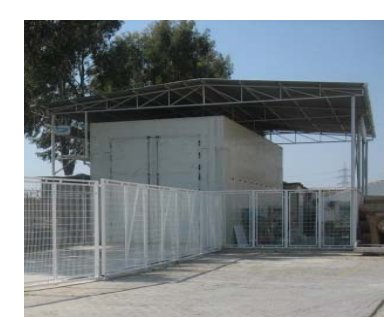

(a)

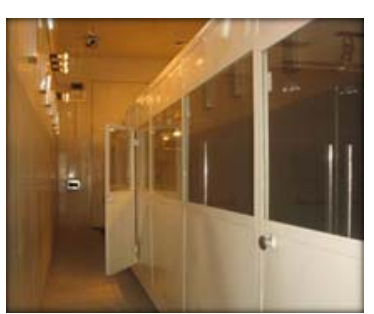

(b)
Fig .1 (a). Outdoor test room (b). Inner test room (with the permission of SAFKAR INC.).

\section{B. Test Procedure}

The performance parameters, namely the pressure drop, the cooling capacity, the energy consumption and the COP, were calculated using the data collected from the refrigerant side. The temperatures of the refrigerant were measured continuously at the inlets and exits of the heat exchangers using four PT-100 sensors and recorded with a data logger. The pressures at the inlet and outlet of the evaporator were measured and recorded every 10 seconds with an electronic manifold. The pressures at the inlet and exit of the condenser were measured with an electronic manifold, but recorded manually every 5 minutes. The indoor and outdoor air temperatures were also measured with PT-100 sensors and recorded with the data logger continuously. The measurement devices used during the experiments and their 
uncertainties are given in Table I. The measurement points on the system and a picture of the prototype mounted on the roof of the test room are given in Fig. 2(a) and Fig. 2(b), respectively.

\begin{tabular}{lc}
\multicolumn{2}{c}{ TABLE I: UNCERTAINTIES } \\
\hline \hline Measurement Device & Uncertainity \\
\hline PT 100 & $\pm 0.1^{\circ} \mathrm{C}$ \\
Testo 570-2 Digital Manifold & $\pm 0.5 \%$ \\
(Evaporator inlet and outlet pressures) & \\
Testo 557-2 Digital Manifold & $\pm 0.5 \%$ \\
(Condenser inlet and outlet pressures) & \\
\hline \hline
\end{tabular}

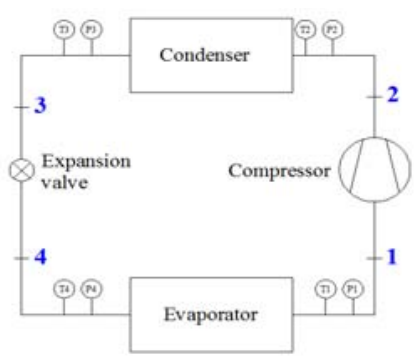

(a)

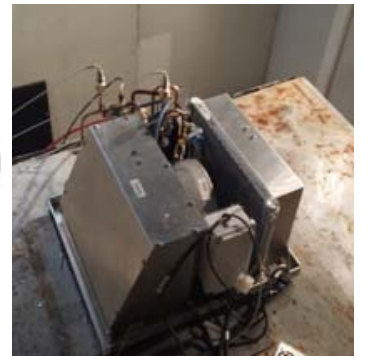

(b)
Fig. 2. (a). Test schematic (b). Prototype mounted on the roof of the inner test room.

\section{Modelling}

The following assumptions are made for energy and exergy analyses of the system.

- All processes are steady state and steady flow with negligible potential and kinetic energy effects.

- The pressure losses in the pipelines connecting the components are negligible, since their lenghts are short.

- Heat losses/gains between the environment and system components are ignored.

- The experimental data used in the calculations are average values during the whole test period. The thermodynamic properties of the refrigerants are obtained using the Refprop software package, developed by NIST [17].

- Since there are not any flowmeters installed in the system to measure the mass flow rate of the refrigerant, all the obtained results are on the unit mass basis.

- The mechanical $\left(\eta_{\mathrm{m}}\right)$ and electrical efficiencies $\left(\eta_{\mathrm{el}}\right)$ of the compressor are taken to be 0.85 and 0.90 , respectively.

- The power consumptions of the condenser and evaporator fans are assumed to be negligible.

- High and low temperature are taken as the averages of the test period, which are $35^{\circ} \mathrm{C}$ and $27^{\circ} \mathrm{C}$, respectively.

- The values for the reference state temperature and pressure are taken to be $30{ }^{\circ} \mathrm{C}$ and $101.325 \mathrm{kPa}$, respectively.

General energy, entropy and exergy balance equations are reduced to specific equations for each component illustrated in Fig. 2 and are given below [12].

Compressor:

$$
\begin{gathered}
w=h_{2}-h_{1} \\
e x_{d e s t, \text { comp }}=T_{0}\left(s_{2}-s_{1}\right)=\psi_{1}-\psi_{2}+w
\end{gathered}
$$

$$
\varepsilon_{\text {comp }}=\frac{\psi_{2}-\psi_{1}}{h_{2}-h_{1}}=1-\frac{e x_{d e s t, c o m p}}{w}
$$

The mechanical-electrical losses can be obtained from:

$$
e x_{d e s t, c o m p, \text { mech }, e l}=\left(1-\eta_{m} \eta_{e l}\right) w_{e l}
$$

With

$$
w_{e l}=\frac{h_{2}-h_{1}}{\eta_{m} \eta_{e l}}
$$

The internal irreversibility due to the fluid friction is calculated from:

$$
e x_{d e s t, c o m p, \text { int }}=e x_{d e s t, c o m p}-e x_{d e s t, c o m p, m e c h, e l}
$$

Condenser:

$$
q_{H}=h_{2}-h_{3}
$$

$$
\begin{gathered}
e x_{\text {dest,cond }}=T_{0}\left(s_{3}-s_{2}+\frac{q_{H}}{T_{H}}\right)=\psi_{2}-\psi_{3}-q_{H}\left(1-\frac{T_{0}}{T_{H}}\right) \\
\varepsilon_{\text {cond }}=\frac{q_{H}\left(1-T_{0} / T_{H}\right)}{\psi_{2}-\psi_{3}}=1-\frac{e x_{d e s t, \text { cond }}}{\psi_{2}-\psi_{3}}
\end{gathered}
$$

Expansion valve:

$$
\begin{gathered}
h_{3}=h_{4} \\
e x_{d e s t, \text { exp }}=T_{0}\left(s_{4}-s_{3}\right)=\psi_{3}-\psi_{4} \\
\varepsilon_{\text {exp }}=\frac{\psi_{4}}{\psi_{3}}
\end{gathered}
$$

Evaporator:

$$
\begin{gathered}
q_{L}=h_{1}-h_{4} \\
e x_{\text {dest }, \text { vap }}=T_{0}\left(s_{1}-s_{4}+\frac{q_{L}}{T_{L}}\right)=\psi_{4}-\psi_{1}+q_{L}\left(1-\frac{T_{0}}{T_{L}}\right) \\
\varepsilon_{\text {evap }}=\frac{q_{H}\left(T_{0}-T_{L}\right) / T_{L}}{\psi_{4}-\psi_{1}}=1-\frac{e x_{\text {dest }, \text { evap }}}{\psi_{4}-\psi_{1}} \\
\psi_{i}=h_{i}-h_{0}-T_{0}\left(s_{i}-s_{0}\right)
\end{gathered}
$$

The COP of the refrigeration cycle can be calculated using (6), while the COP of the system including mechanical and electrical losses can be determined from (6b):

$$
C O P_{\text {cycle }}=\frac{q_{L}}{w}
$$




$$
C O P_{\text {system }}=\frac{q_{L}}{w}
$$

The overall exergy efficiency based on product/fuel basis can be calculated from:

$$
\varepsilon_{\text {cycle }}=\frac{\sum \text { specific exergetic product }}{\sum \text { specific exergetic fuel }}=\frac{\sum p_{i}}{\sum f_{i}}
$$

The functional exergy efficiency of the system may also be calculated using:

$$
\varepsilon_{f u n c}=\frac{e x_{4}-e x_{1}}{w_{e l}}
$$

Van Gool's improvement potential on unit mass basis is given by:

$$
i p=(1-\varepsilon)\left(e x_{i n}-e x_{\text {out }}\right)
$$

Relative irreversibility values for each component can be obtained from:

$$
R I=\frac{e x_{d e s t, i}}{e x_{d e s t, t o t}}
$$

Total specific exergy destruction can be derived from:

$$
e x_{\text {dest }, \text { tot }}=e x_{\text {dest, comp }}+e x_{d e s t, \text { cond }}+e x_{\text {dest }, \text { xp }}+e x_{\text {dest }, \text { evap }}
$$

\section{RESUltS AND DisCUSSION}

The pressure values at the inlet and exit of the evaporator and condenser, the pressure drop in each heat exchanger and the compression ratio are also calculated and given in Table II, which are based on the average values taken during the whole test period. The pressure of R-1234yf is slightly higher than that of R-134a for the evaporator and lower for the condenser while its compression ratio is approximately $20 \%$ lower.

Pressure-enthalpy and temperature-entropy diagrams of both refrigerants are illustrated and compared to each other in Fig. 3 and Fig. 4, respectively. As it can be seen in Fig. 3, the specific cooling capacity of R-134a is significantly higher than that of R-1234yf while its specific compression work is slightly lower than that of R-1234yf. The lower compression work of R-1234yf causes an improvement in the COP of the system. The difference between the COP values of the two systems is, therefore, within the range of $9 \%$.

TABLE II: AVERAGE PRESSURE VALUES OF THE REFRIGERANTS

\begin{tabular}{c|ccccccc}
\hline \hline \multicolumn{7}{c}{} & \multicolumn{5}{c|}{ Pressure (kPa) } & \multicolumn{2}{c|}{ Pressure Drop (kPa) } & $\begin{array}{c}\text { Compression } \\
\text { Ratio }\end{array}$ \\
\hline Refrigerant & Evap. Inlet & Evap. Outlet & Cond. Inlet & Cond. Outlet & Evaporator & Condenser & \\
R-134a & 447 & 402 & 1520.88 & 1512.19 & 45 & 3.7 & 3.78 \\
R-1234yf & 499 & 440 & 1341.86 & 1331.79 & 58.16 & 10.1 & 3.05 \\
\hline \hline
\end{tabular}

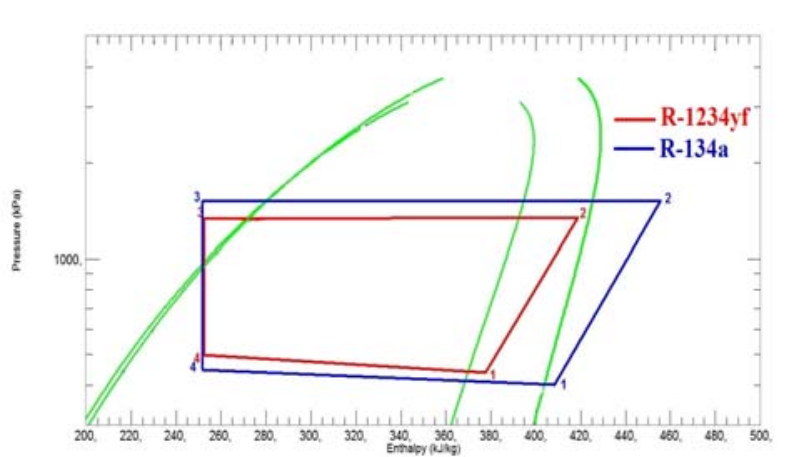

Fig. 3. Ln P - h diagram comparison of R-134a and R-1234yf.

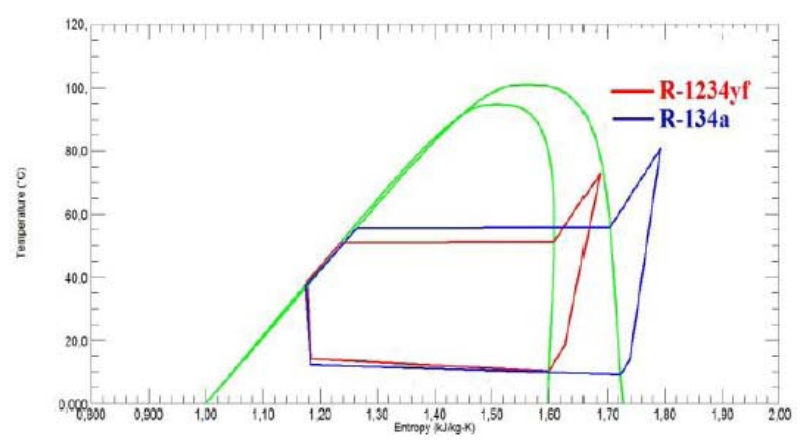

Fig. 4. T - s diagram diagram comparison of R-134a and R-1234yf.

Temperature and pressure values and corresponding specific enthalpy, entropy and exergy values are listed in
Table III for both refrigerants, while Table IV presents some energetic and exergetic data for the system based on the specific values. The electrical work input $\left(w_{e l}\right)$ is calculated from (1e) and found to be $61.52 \mathrm{~kJ} / \mathrm{kg}$ for R-134a and 53.75 for R-1234yf. The greatest irreversibility/exergy destruction occurs on the compressor of the system for both refrigerants and it is followed by the condenser, evaporator and the expansion valve. The irreversibility related to expansion valve is relatively very small and it is due to the pressure drop of the refrigerant. In terms of exergy efficiencies the following inequality can be written for both refrigerants:

$$
\varepsilon_{\text {exp }}>\varepsilon_{\text {comp }}>\varepsilon_{\text {cond }}>\varepsilon_{\text {evap }}
$$

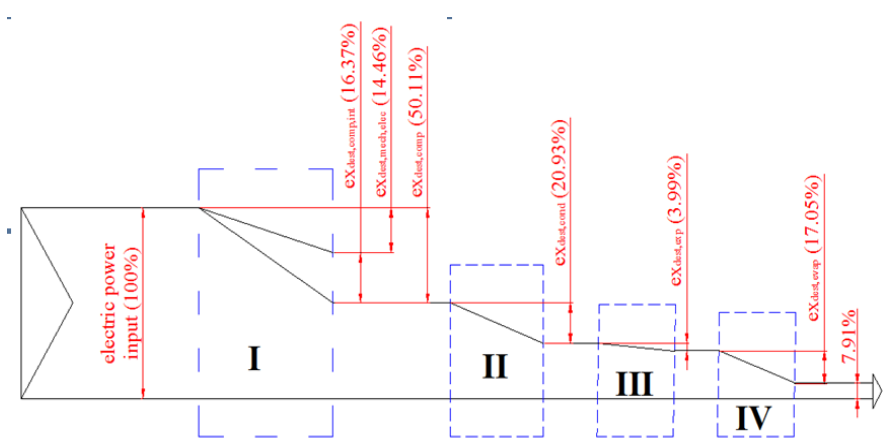

Fig. 5. Exergy flow and loss (Grasmann) diagram for R-134a. 
The overall exergy efficiency values on product/fuel basis for R-134a and R-1234yf are found to be $58.72 \%$ and $57.39 \%$, respectively, while the functional exergy efficiencies are determined as $19.59 \%$ for R-134a and $17.22 \%$ for R-1234yf.

Van Gool's improvement potential given in (8) is calculated for each component of the refrigeration system and the results are listed in Table IV. It is found that for $\mathrm{R}-134 \mathrm{a}$, the compressor has the highest exergetic improvement potential $(15.45 \mathrm{~kJ} / \mathrm{kg})$ followed by the condenser, evaporator and expansion valve with 10.25, 9.13 and $0.13 \mathrm{~kJ} / \mathrm{kg}$, respectively. Similarly, the highest ip value for R-1234yf occurred in the compressor due to its high exergy destruction. The evaporator has an exergetic improvement potential of $6.92 \mathrm{~kJ} / \mathrm{kg}$, which is very close to the value of the condenser $(6.56 \mathrm{~kJ} / \mathrm{kg})$. The ip value of the expansion valve for R-1234yf is found to be $0.12 \mathrm{~kJ} / \mathrm{kg}$.

One way to see the results of exergy analysis is to draw exergy flow and loss (Grassmann) diagrams for the systems studied. In this regard, the two Grasmann diagrams are drawn for an exergy input of 100\% and illustrated in Fig. 5 and Fig. 6 for R-134a and R-1234yf, respectively.

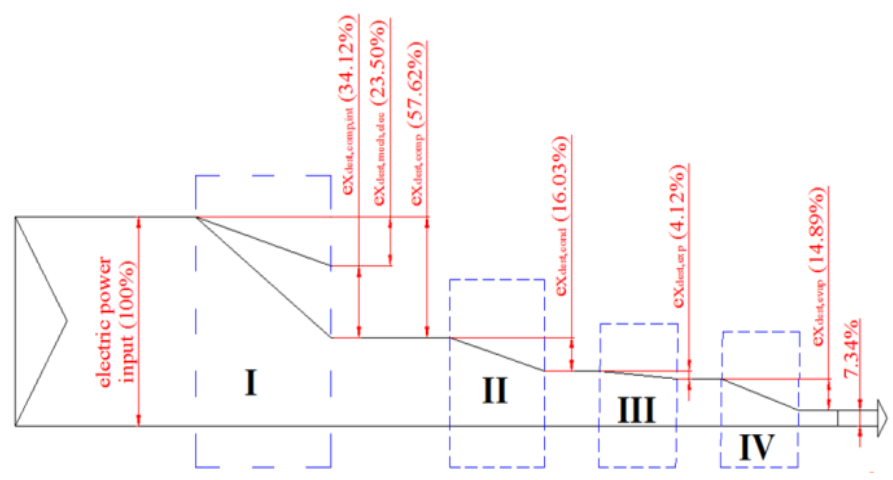

Fig. 6. Exergy flow and loss (Grasmann) diagram for R-1234yf.

TABLE III: DATA USED IN THE ANALYSES

\begin{tabular}{|c|c|c|c|c|c|}
\hline STtate & $\bar{~} 0$ & 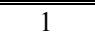 & 2 & $\overline{3}$ & $\bar{~} \overline{4}$ \\
\hline Description & - & $\begin{array}{c}\text { Evap. } \\
\text { outlet/ } \\
\text { Comp. } \\
\text { inlet }\end{array}$ & $\begin{array}{c}\text { Comp. } \\
\text { outlet/ } \\
\text { Cond.in } \\
\text { let }\end{array}$ & $\begin{array}{l}\text { Cond. } \\
\text { outlet/ } \\
\text { Exp. } \\
\text { inlet }\end{array}$ & $\begin{array}{c}\text { Exp. } \\
\text { outlet/ } \\
\text { Evap. } \\
\text { inlet }\end{array}$ \\
\hline Phase & $\begin{array}{l}\text { Dead } \\
\text { state }\end{array}$ & $\begin{array}{c}\text { Super } \\
\text { heated } \\
\text { vapor }\end{array}$ & $\begin{array}{c}\text { Super } \\
\text { heated } \\
\text { vapor }\end{array}$ & $\begin{array}{c}\text { Saturat } \\
\text { ed } \\
\text { liquid }\end{array}$ & Mixture \\
\hline Fluid & \multicolumn{5}{|c|}{ R-134a } \\
\hline $\begin{array}{c}\text { Temperature } \\
\left({ }^{\circ} \mathrm{C}\right)\end{array}$ & 30.00 & 14.06 & 80.86 & 37.01 & 12.73 \\
\hline $\begin{array}{c}\text { Pressure, } \\
(\mathrm{kPa})\end{array}$ & 101.325 & 402.00 & $\begin{array}{c}1520.9 \\
0\end{array}$ & $\begin{array}{c}1512.2 \\
0\end{array}$ & 447.00 \\
\hline $\begin{array}{c}\text { Specific } \\
\text { enthalpy } \\
(\mathrm{kJ} / \mathrm{kg})\end{array}$ & 428.80 & 408.46 & 455.52 & 251.90 & 251.90 \\
\hline $\begin{array}{c}\text { Specific } \\
\text { entropy } \\
(\mathrm{kJ} / \mathrm{kg} \cdot \mathrm{K})\end{array}$ & 1.9148 & 1.7389 & 1.7929 & 1.1746 & 1.1827 \\
\hline $\begin{array}{c}\text { Specific } \\
\text { exergy } \\
(\mathrm{kJ} / \mathrm{kg}) \\
\end{array}$ & - & 32.98 & 63.67 & 47.49 & 45.04 \\
\hline Fluid & \multicolumn{5}{|c|}{ R-1234yf } \\
\hline $\begin{array}{c}\text { Temperature } \\
\left({ }^{\circ} \mathrm{C}\right) \\
\end{array}$ & 30.00 & 18.23 & 72.84 & 38.51 & 14.26 \\
\hline
\end{tabular}

\begin{tabular}{c|ccccc}
\hline $\begin{array}{c}\text { "Pressure, } \\
(\mathrm{kPa})\end{array}$ & 101.325 & 440.00 & $\begin{array}{c}1341.9 \\
0\end{array}$ & $\begin{array}{c}1331.8 \\
0\end{array}$ & 499.00 \\
\hline $\begin{array}{c}\text { Specific } \\
\text { enthalpy } \\
(\mathrm{kJ} / \mathrm{kg})\end{array}$ & 394.99 & 377.64 & 418.76 & 252.63 & 252.63 \\
\hline $\begin{array}{c}\text { Specific } \\
\text { entropy } \\
(\mathrm{kJ} / \mathrm{kg} \cdot \mathrm{K})\end{array}$ & 1.7869 & 1.6271 & 1.6876 & 1.1769 & 1.1842 \\
\hline $\begin{array}{c}\text { Specific } \\
\text { exergy } \\
(\mathrm{kJ} / \mathrm{kg})\end{array}$ & - & 31.09 & 53.87 & 42.56 & 40.35 \\
\hline \hline
\end{tabular}

TABLE IV: RESULTS OF THE ENERGY AND EXERGy ANALYSES BASED ON SPECIFIC VALUES

\begin{tabular}{|c|c|c|c|c|}
\hline Fluid & \multicolumn{4}{|c|}{ R-134a } \\
\hline Component & Evaporator & Compressor & Condenser & $\begin{array}{c}\text { Expansion } \\
\text { valve }\end{array}$ \\
\hline $\begin{array}{l}\text { Capacity } \\
(\mathrm{kJ} / \mathrm{kg})\end{array}$ & 156.56 & 47.06 & 203.62 & - \\
\hline $\begin{array}{l}\text { Exergetic product } \\
(\mathrm{kJ} / \mathrm{kg})\end{array}$ & 1.56 & 30.69 & 3.30 & 45.04 \\
\hline $\begin{array}{l}\text { Exergetic } \\
\text { fuel } \\
(\mathrm{kJ} / \mathrm{kg})\end{array}$ & 12.05 & 61.52 & 16.18 & 47.49 \\
\hline $\begin{array}{c}\text { Exergy destruction } \\
(\mathrm{kJ} / \mathrm{kg})\end{array}$ & 10.49 & 30.83 & 12.88 & 2.46 \\
\hline $\begin{array}{c}\text { Exergy efficiency } \\
(\%)\end{array}$ & 12.98 & 49.89 & 20.42 & 94.83 \\
\hline $\begin{array}{c}\text { Exergetic } \\
\text { improvement } \\
\text { potential } \\
(\mathrm{kJ} / \mathrm{kg})\end{array}$ & 9.13 & 15.45 & 10.25 & 0.13 \\
\hline $\begin{array}{c}\text { Relative } \\
\text { irreversibility (\%) }\end{array}$ & 18.51 & 54.42 & 22.73 & 4.33 \\
\hline COP of the system & \multicolumn{4}{|c|}{2.55} \\
\hline $\begin{array}{c}\text { Exergy efficiency of } \\
\text { the cycle }(\%)\end{array}$ & \multicolumn{4}{|c|}{58.72} \\
\hline $\begin{array}{c}\text { Functional exergy } \\
\text { efficiency of the } \\
\text { system }(\%)\end{array}$ & \multicolumn{4}{|c|}{19.59} \\
\hline Fluid & \multicolumn{4}{|c|}{ R-1234yf } \\
\hline Component & Evaporator & Compressor & Condenser & $\begin{array}{c}\text { Expansion } \\
\text { valve }\end{array}$ \\
\hline $\begin{array}{l}\text { Capacity } \\
(\mathrm{kJ} / \mathrm{kg})\end{array}$ & 125.01 & 41.12 & 166.13 & - \\
\hline $\begin{array}{c}\begin{array}{c}\text { Exergetic product } \\
(\mathrm{kJ} / \mathrm{kg})\end{array} \\
\end{array}$ & 1.25 & 22.78 & 2.70 & 40.35 \\
\hline $\begin{array}{c}\text { Exergetic } \\
\text { fuel } \\
(\mathrm{kJ} / \mathrm{kg}) \\
\end{array}$ & 9.26 & 53.75 & 11.31 & 42.56 \\
\hline $\begin{array}{c}\begin{array}{c}\text { Exergy destruction } \\
(\mathrm{kJ} / \mathrm{kg})\end{array} \\
\end{array}$ & 8.01 & 30.97 & 8.62 & 2.21 \\
\hline $\begin{array}{c}\text { Exergy efficiency } \\
(\%)\end{array}$ & 13.50 & 42.38 & 23.83 & 94.80 \\
\hline $\begin{array}{c}\text { Exergetic } \\
\text { improvement } \\
\text { potential } \\
(\mathrm{kJ} / \mathrm{kg})\end{array}$ & 6.92 & 17.85 & 6.56 & 0.12 \\
\hline $\begin{array}{c}\text { Relative } \\
\text { irreversibility } \\
(\%)\end{array}$ & 16.07 & 62.19 & 17.30 & 4.44 \\
\hline COP of the system & \multicolumn{4}{|c|}{2.33} \\
\hline $\begin{array}{c}\text { Exergy efficiency of } \\
\text { the cycle }(\%)\end{array}$ & \multicolumn{4}{|c|}{57.39} \\
\hline $\begin{array}{c}\text { Functional exergy } \\
\text { efficiency of the } \\
\text { system }(\%)\end{array}$ & \multicolumn{4}{|c|}{17.22} \\
\hline
\end{tabular}

\section{CONCLUSIONS}

An EAC unit is experimentally investigated and it's performance is evaluated using exergy analyses. The specific exergy destructions, exergy efficiencies, exergetic improvement potentials and relative irreversibilities are 
calculated for each component and comparisons are made between the refrigerants.

Some concluding remarks can be listed as follows:

The legislations related to the contribution of the existing refrigerants to global warming make it necessary to use alternative refrigerants with low GWP, such as R-1234yf.

R-134a showed a slightly better performance in drop-in tests. The cooling effect of R-1234yf is found to be approximately $20 \%$ lower, while the compression work of $\mathrm{R}-134 \mathrm{a}$ is about $13 \%$ higher than that of R-1234yf on the basis of the specific enthalpy values. The lower compression work causes an improvement in the COP. The COP values of $\mathrm{R}-134 \mathrm{a}$ and R-1233yf are 2.55 and 2.33, respectively. $\mathrm{R}-1234 \mathrm{yf}$ has higher pressure values than R-134a for both heat exchangers. While the pressure drop values in the evaporator and condenser are $58.16 \mathrm{kPa}$ and $10.1 \mathrm{kPa}$ for R-1234yf, they are 45 and 8.7 for R-134a, respectively.

No important difference is found between the exergy efficiencies of the refrigerants. The exergetic efficiency values based on product/fuel basis are found to be $58.72 \%$ and $57.39 \%$ for R-134a and R-1234yf, respectively. On the other hand the functional exergy efficiencies are $19.59 \%$ for R-134a and $17.22 \%$ for R-1234yf.

For a further work, it is recommended to conduct more tests with a refrigerant flowmeter to get the exergetic parameters on rate basis. Additionally, exergoenvironmental analysis can be performed to assess the environmental benefits of R-1234yf in comparison with R-134a. Exergoecomomic analysis may also be performed to show the effect of the high cost of R-1234yf, which is due to the insufficient production capacity.

\section{ACKNOWLEDGMENT}

The authors are very grateful to the Republic of Turkey Ministry of Science, Industry and Technology for the support given to this project through the program called "SAN-TEZ". They also thank DuPont for providing a free sample of R-1234yf and R\&D personnel of SAFKAR INC., Izmir, Turkey for their support and help during performing the tests.

\section{REFERENCES}

[1] J. M. Calm, "The next generation of refrigerants - Historical review, considerations, and outlook," International Journal of Refrigeration, vol. 31, pp. 1123-1133, 2006.

[2] Directive 2006/40/EC of the European Parliament and of the Council of 17 May 2006 Relating To Emissions from Air-Conditioning Systems in Motor Vehicles And Amending Council Directive 70/156/EEC, Office Journal of the Europian Union, 2006.

[3] The European Parliament. European Parliament legislative resolution of 12 March 2014 on the proposal for a regulation of the European Parliament and of the Council on fluorinated greenhouse gases (COM(2012)0643 - C7-0370/2012 - 2012/0305(COD)). [Online]. Available:

http://ec.europa.eu/clima/policies/f-gas/legislation/docs/fluorinated_gr eenhouse_gases_en.pdf.

[4] M. Jarahnejad, "New low GWP synthetic refrigerants," Master of Science Thesis, Industrial Engineering and Management, KTH, Stockholm, 2012.

[5] K. Tanaka and Y. Higashi, "Thermodynamic properties of HFO-1234yf (2, 3, 3, 3-tetrafluoropropene)," International Journal of Refrigeration, vol. 33, pp. 474-479, 2010.

[6] T. A. Lewandowski, Additional risk Assessment of Alternative Refrigerant R-1234yf, 2013, pp. 1-29.

[7] M. Koban, "Automotive material investigation with low GWP refrigerant HFO-1234yf," in Proc. Vehicle Thermal Management
Systems Conference and Exhibition (VTMS10), Willmington, DE, 2011, pp. 11-18.

[8] T. Ikegami, M. Iguchi, K. Aoki, and K. Iijima, "New refrigerants evaluation results," presented at the SAE 2008 Alternate Refrigerant Systems Symposium, Arizona, 2008.

[9] M. Kauffeld, Availability of Low GWP Alternatives to HFCs-Feasibility of an early Phase-Out of HFCs by 2020, Environmental Investigation Agency, Inc., 2012.

[10] R. Monforte, B. Rose, and J. -M. L'Huillier, "Updated situation about alternate refrigerant evaluation," presented at the SAE 2008 Alternate Refrigerant Systems Symposium, Scottsdale, AZ, 2008.

[11] T. J. Leck, "New high performance low GWP refrigerants for stationary AC and refrigeration," in Proc. International Refrigeration and Air Conditioning Conference, Purdue, 2011, pp. 1-8.

[12] A. Hepbasli, "Exergetic modeling and assessment of solar assisted domestic hot water tank integrated ground-source heat pump systems for residences," Energy and Buildings, vol. 39, pp. 1211-1217, 2007.

[13] J. U. Ahamed, R. Saidur, and H. H. Masjuki, "A review on exergy analysis of vapor compression refrigeration system," Renewable and Sustainable Energy Reviews, vol. 15, pp. 1593-1600, 2011.

[14] A. E. Özgür, A. Kabul, and Ö. Kizilkan, "Exergy analysis of refrigeration systems using an alternative refrigerant (HFO-1234yf) to R-134a," International Journal of Low-Carbon Technologies, vol. 9, pp. 1-7, 2012.

[15] M. Araz, A. Güngör, H. Yaldırak, and H. G. Özcan, "Utilization possibilities of R-1234yf in automobile industry," in Proc. 1st National Air Conditioning Refrigeration Education Symposium and Exhibition, 2012. (in Turkish)

[16] M. Araz, A. Güngör, and A. Hepbasli, "Assessment of the use of Low Global Warming Potential (LGWP) refrigerants in refrigeration applications," in Proc. 11th National HVAC and Sanitary Convention and Exhibition (TESKON 2013), 2013, vol. 1, pp. 573-604. (in Turkish)

[17] E. W. Lemmon, M. L. Huber, and M. O. McLinden, NIST Standard Reference Database 23: Reference Fluid Thermodynamic and Transport Properties-REFPROP, version 9.1, National Institute of Standards and Technology, Standard Reference Data Program, Gaithersburg, 2013.

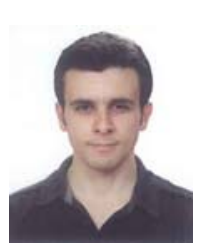

M. Araz was born in Karaman, Turkey on August 23, 1986. He received B.S. degree in mechanical engineering from Ege University, Turkey in 2010, M.S degree in 2013 and is currently a Ph.D. student in mechanical Engineering at Ege University.

He completed his military service in 2011. He has been working as a research assistant in the Energy Systems Engineering Department of Yaşar University, in İzmir, since October, 2012. He has worked as scholarship student in the project entitled "Design of an Elevator Air Conditioning Unit Using R-1234yf", which is supported by the Republic of Turkey Ministry of Science, Industry and Technology. His research interests are low global warming potential (LGWP) refrigerants, air conditioning systems, refrigeration technologies and clean energy systems.

Mr. Araz is a member of Union of Chambers of Turkish Engineers and Architects the Chamber of Mechanical Engineers.

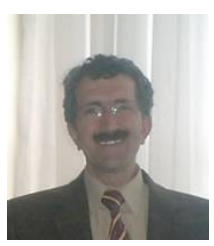

A. Güngör was born in Elazı̆ğ, Turkey in 1955 and has two daughters. He received B.S in mechanical engineering in 1977 and M.S. in 1978 from the Department of Mechanical Engineering of Ege University, Turkey and a Ph.D. in 1985 from the Solar Energy Institute of the same university.

He conducted research at the Brace Research Institute, Canada in 1986 for 6 months. He became an associate professor in the field of Heat and Mass Transfer in 1989 and a professor in 1996 at Ege University. He has worked in different institutions including Department of Mechanical Engineering of Dokuz Eylül University, Solar Energy Institute and Department of Mechanical Engineering of Ege University since 1978. He was the head of the Department of Mechanical Engineering of Ege University between 1997 and 2012 and is still serving at the same department as the head of Thermodynamics Division. His research interests are air conditioning, solar thermal energy applications, refrigeration technique, absorption and adsorption refrigeration technologies, drying technique, heat pipes, thermodynamics and heat and mass transfer applications.

Professor Güngör is a member of Union of Chambers of Turkish Engineers and Architects the Chamber of Mechanical Engineers, Turkish Heat Science and Technique Association and ASHRAE. 
A. Hepbasli was born in Izmir, Turkey on June 27, 1958 $\mathrm{He}$ received B.S. (first class honor) in mechanical engineering from Selcuk University (SU), Turkey in 1980, M.S. from Istanbul Technical University of Istanbul, Turkey in 1985 and a Ph.D. in mechanical engineering from Selcuk University in 1990 while he was working in industry. He joined Ege University in 1996 after about a ten-year period in industry at different positions and a one-year period at Izmir Branch Office of Chamber of Mechanical Engineers as a consultant. He has been appointed as the Head of Energy Systems Engineering Department at Yaşar University in Izmir, Turkey since September 2012. He is the author and co-author of over 530 papers (over 250
SCI-based papers with an h-index of 34) on a national and international basis as well as several national and international books and book chapters. His research has been involved with energy, exergy, exergoeconomic and exergoenvironmental analyses and assessments of energy-related systems, energy/exergy efficiency and management, clean energy technologies, ground-source heat pumps, utilization and potential of renewable energy sources and sustainable energy technologies. He has served as a consultant for industry in cases involving his research area and is also a member in the international advisory board of eight prestigious energy-related journals, and an associate editor of Journal of Energy Engineering (ASCE) while also serving many energy journals and industrial projects as a reviewer. 